\title{
Sodium Channels in Normal and Regenerated Feline Ventral Spinal Roots
}

\author{
Henry W. Querfurth, Regina Armstrong, and Robert M. Herndon \\ Center for Brain Research, University of Rochester School of Medicine and Dentistry, Rochester, New York
}

Regenerated and remyelinated nerve fibers have shorter internodes and thus more nodes than normal mature fibers. This requires either a decrease in the number of sodium channels per node or an increase in the number of channels per fiber or both. The purpose of this investigation was to determine what happens to sodium channel number, as estimated by ${ }^{3} \mathrm{H}$-saxitonin (STX) binding, in regenerated fibers and to relate this to nodal number. Five adult cats underwent cryoaxotomy of ventral root levels $L 5, L 6, L 7$, and $S 1$ on the left side. After regeneration for 16-45 weeks, binding parameters were determined. On the right (control) side, binding was consistent with that in unoperated animals $(b=1.3$, $B_{\max }=10.2 \pm 0.4 \mathrm{fmol} / \mathrm{mg}$ wet, $K_{d}=0.6 \pm 0.1 \mathrm{~nm}$ ). However, the regenerated nerves showed a 3.5 -fold increase in maximal binding $\left(b=1.3, B_{\max }=36.1 \pm 0.5, K_{d}=0.45 \pm 0.4\right)$.

Computer-aided histologic analysis of the regenerated roots revealed (1) a decrease in fiber size; (2) a significant decrease in internodal length for fibers in a given size class; and (3) a 1.35-fold increase in total fibers per root. These factors account for a 2.36-fold increase in nodes per milligram (wet). The number of STX binding sites per regenerated node was calculated to be $1.95 \times 10^{6}(1.31,3.07,95 \%$ confidence limits), whereas it was $1.26 \times 10^{6}(0.78,2.02)$ for the control roots. The difference was not significant $(p>0.05)$.

It is concluded that, in regeneration, the increase in nodal number is accompanied by an increase in sodium channels, so that the number of channels per node is normal or slightly increased. There is a marked increase in channels per fiber and an even greater increase in channels per anterior horn cell. The implications of these data for nodal reorganization in remyelination are discussed.

Recent evidence suggests that ionic channel reorganization must play an important role in recovery of function following demyelination. Several observations indicate that remyelination and restoration of conduction velocity are not essential for restoration of function following demyelination in multiple sclerosis (Namerow and Thompson, 1969; Ghatak et al., 1974; McDonald, 1974a, b; Wisniewski et al., 1976; Herndon et al.,

\footnotetext{
Received Apr. 25, 1986; revised Oct. 17, 1986; accepted Dec. 23, 1986.

This work was supported by PHS Grant GM 07356 and NS 15283. We thank Ted Begenesich, Ph.D., Henry Davis, Ph.D., and Mr. Steven Fram for their help in the statistical and programming aspects of this work. We also express gratitude for the help of Mrs. Mary Capozzi and Mrs. Nancy Dintruff in the preparation of the manuscript.

Correspondence should be addressed to Henry W. Querfurth, M.D., Ph.D., Divison of Neurology, Box RG-27, University of Washington, University Hospital, Seattle, WA 98195.

Copyright (c) 1987 Society for Neuroscience $0270-6474 / 87 / 061705-12 \$ 02.00 / 0$
}

1977; Ritchie and Rogart, 1977b, c; Prineas and Connell, 1979; Rasminsky, 1980). The importance of paranodal function for conduction and activity-dependent excitability in the course of experimental demyelination supports the view that changes in sodium channel numbers and distribution are critical to restoration of function (Morgan-Hughes, 1968; Smith and Hall, 1980, 1982; LaFontaine et al., 1982).

The concept of channel reorganization was developed on the basis of several electrophysiological reports (Huxley and Stampfli, 1949; McDonald, 1963; McDonald and Sears, 1970; Rasminsky and Sears, 1972; Chiu and Ritchie, 1982) and binding data using the specific sodium channel marker saxitoxin $\left({ }^{3} \mathrm{H}-\right.$ STX) (Ritchie and Rogart, 1977a; Waxman and Ritchie, 1981), which collectively indicate that there are insufficient sodium channels in the internodal regions of normal axons to suport regenerative currents after the loss of myelin. This inference was strengthened by demonstrating the delayed appearance of excitability in demyelinated axolemma (Bostock and Sears, 1976; Foster et al., 1980).

The factors that control internodal length, nodal structure, and sodium channel number and distribution in regenerated or remyelinated fibers are poorly understood. When axons regenerate following axotomy (Sanders and Whitteridge, 1946; Culp and McKenzie, 1981) or when they remyelinate after primary demyelination (Allt, 1969, 1976; Gledhill et al., 1973; Prineas and Connell, 1979), the normal direct fiber size $(D)$-internodal distance $(I)$ relationship is lost, and the newly formed internodal lengths are uniformly reduced in size with a reciprocal increase in the number of nodes (Hiscoe, 1947; Visozo and Young, 1948). Whether the total sodium channel number per fiber remains constant despite an increased number of nodes or whether the number of channels increases with the increase in nodes has been the subject of speculation. The carefully correlated biochemical and morphologic studies necessary to determine what changes occur and how they interrelate have not been reported.

The purposes of this investigation were (1) to reassess the number of sodium channels per node in mammalian peripheral nerve using ${ }^{3} \mathrm{H}-\mathrm{STX}$ binding under equilibrium conditions (Ritchie et al., 1976) and to compare this with data from gating current studies (Chiu, 1980); and (2) to determine what changes occur in sodium channel number as estimated by ${ }^{3} \mathrm{H}-\mathrm{STX}$ binding in regenerated ventral roots and correlate this with changes in nodal number to determine whether the number of channels per node or the number of channels per fiber remains constant in regenerated fibers or whether a more complex relationship exists. An accurate determination of the number of channels per node can be calculated only in a study in which both toxin binding and nodal histology are correlated. 


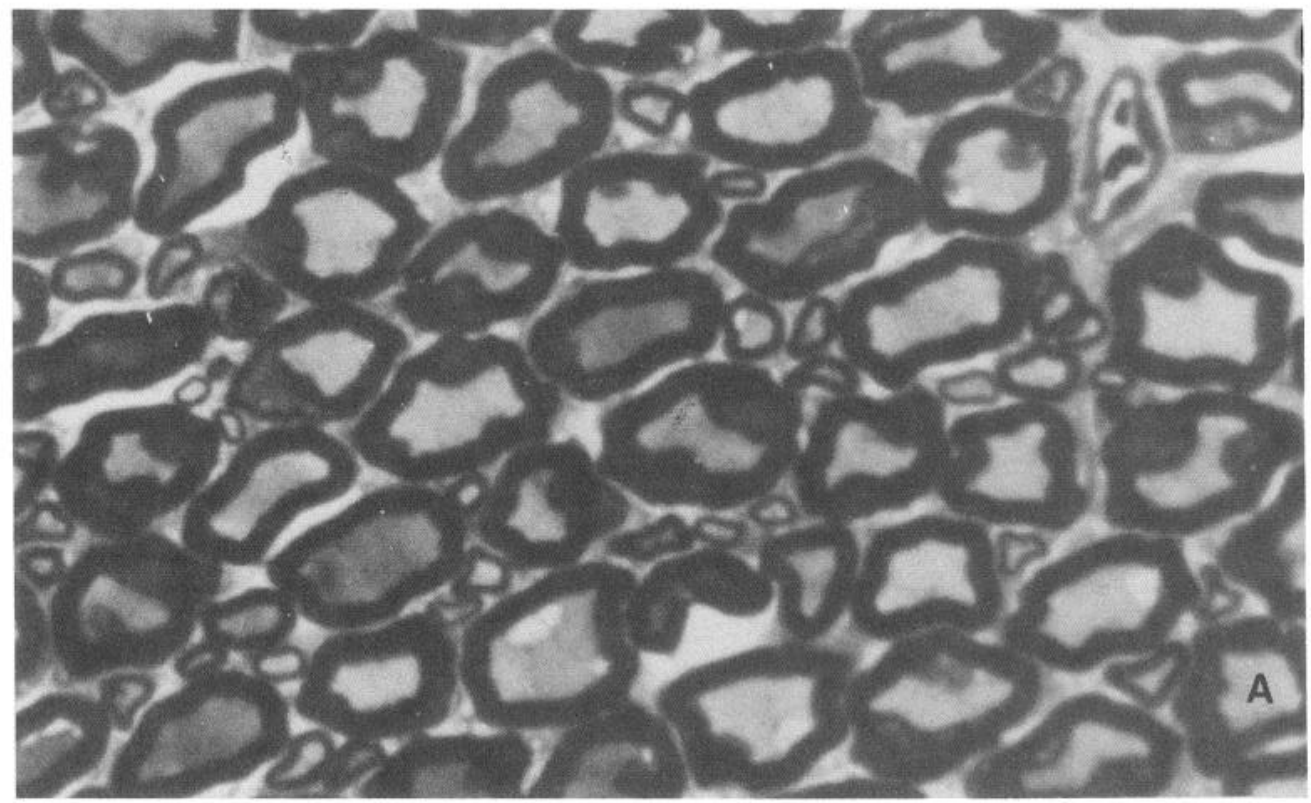

Figure 1. A, High-power light micrograph $(\times 1200)$ of a typical sample area within a control ventral root (cat 18 L5R, 20 weeks) that would be manually digitized to collect axonal, fiber, and extracellular space perimeters and areas. The 2 distinct fiber size populations are evident. Scale, $50 \mu \mathrm{m}$. $B$, High-power micrograph $(\times 1200)$ of the contralateral ventral root (cat $18 \mathrm{~L} 5 \mathrm{~L}$ ). The large fibers are somewhat reduced in size and have thinner myelin sheaths. The evidence for branching in this photo is manifest in several locations by the presence of myelinated satellite axons surrounding a larger axon and even contained with the same basal lamina (center, upper right, and lower right). The endoneurial space is increased. Scale, $50 \mu \mathrm{m}$.

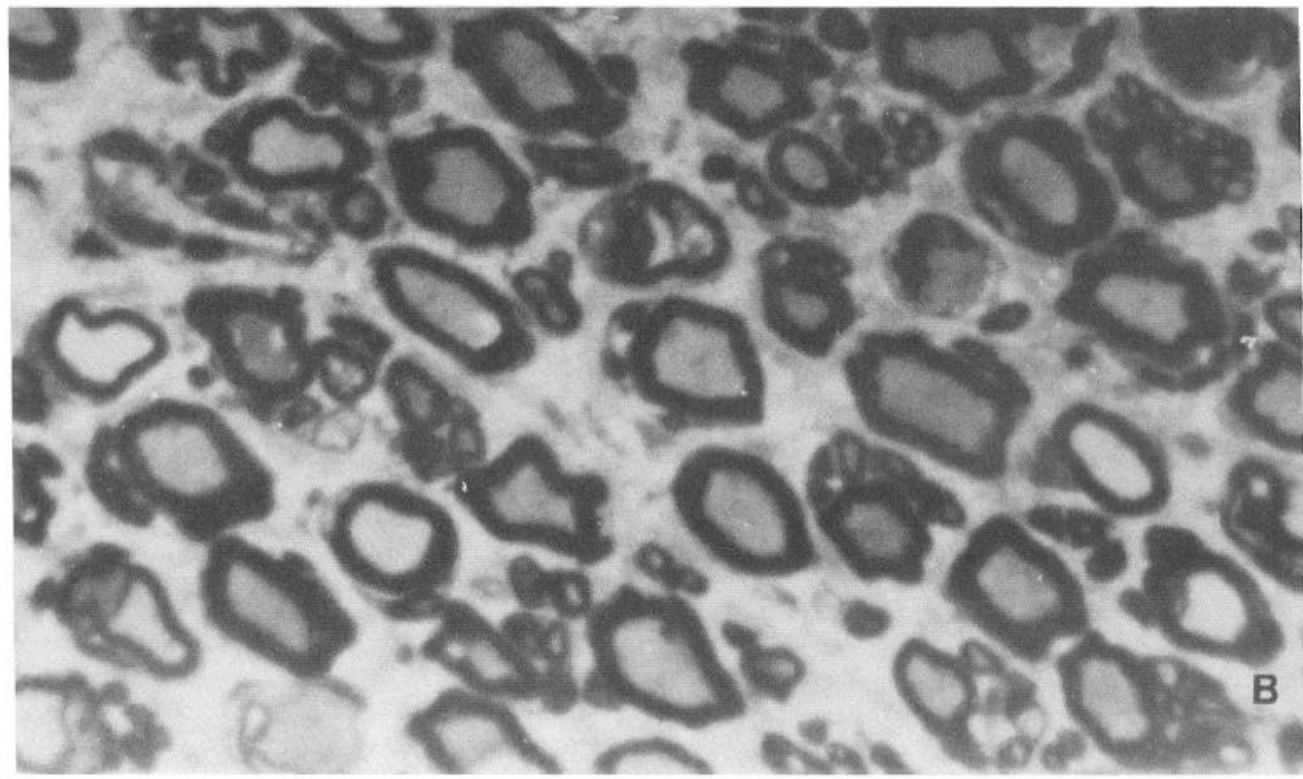

\section{Materials and Methods}

The cat lumbosacral ventral roots $\mathrm{L} 5, \mathrm{~L} 6, \mathrm{~L} 7$, and S1 were chosen for the following characterisitics: (1) scant epi- and perineurial sheathing to minimize trauma in preparation and facilitate equilibrium binding of ${ }^{3} \mathrm{H}-\mathrm{STX},(2)$ a relatively uncomplicated histology reflecting a relatively low degree of contamination by unmyelinated fibers, (3) little branching, and (4) favorable conditions for functional regeneration after interruption (Thulin and Carlsson, 1969; Gamble, 1976; Bray et al., 1981).

Surgery. Preliminary ${ }^{3} \mathrm{H}-\mathrm{STX}$ binding data were obtained from the ventral and dorsal roots of 2 normal cats and morphometric data from another cat. Subsequently, 7 cats were premedicated with $0.1 \mathrm{mg} / \mathrm{kg}$ atropine, anesthetized with $25 \mathrm{mg} / \mathrm{kg}$ sodium pentobarbital, i.v., and intubated. Respiration was maintained on room air using a respirator. Temperature was held at $37^{\circ} \mathrm{C}$ by a heating pad coupled to a rectal thermistor. Using sterile technique, a laminectomy was performed, the dura was opened, and the ventral roots identified. Succinylcholine was infused in a dose of $0.56 \mathrm{mg} / \mathrm{kg}$, and a ventral root was lifted onto a copper probe placed 5-6 mm from the root-cord junction (Fig. 1) and frozen by applying a piece of dry ice to the shaft of the probe. After freezing for $10 \mathrm{sec}$, the root was allowed to thaw and the probe removed. Ventral roots $\mathrm{L} 5, \mathrm{~L} 6, \mathrm{~L} 7$, and $\mathrm{S} 1$ on the left side were cryoaxotomized in this manner. The area was packed with gel foam, and the muscle, fascia, and skin layers closed. Neurological examinations were then performed periodically in the operated cats until clinical improvement ceased. In both the binding experiments and histologic methods to follow, the right (unoperated) ventral root served as control for the left (axotomized) ventral root.

STX binding. Crystalline STX was tritiated by new England Nuclear and purified by the methods of Ritchie et al. (1976); purity was serially determined during the period of the experiments by the method de- 
scribed by Levinson (1975). A radio purity of $0.63 \pm 0.04$ with a halflife of 3.5 months and a true specific activity of $15.2 \times 10^{15} \mathrm{dpm} / \mathrm{mol}$ were obtained for the single batch used on the operated anaimals.

Normal cats and operated cats that had reached maximal recovery were anesthetized and perfused with saline for binding and morphometric studies. The lumbosacral cord was extracted and kept in rabbit Locke solution at $3^{\circ} \mathrm{C}$. The intradural roots L5-S1 were identified and removed and their length-weight relationships recorded before teasing sample fascicles for nodal quantitation and ${ }^{3} \mathrm{H}-\mathrm{STX}$ binding. For each concentration of STX from 0.25 to $25 \mathrm{nM}$, several fascicles weighing $10-25 \mathrm{mg}$ were randomly selected from a pool of mixed fascicles teased from the nerve roots. They were then incubated in glass vials containing ${ }^{3} \mathrm{H}$-STX in $1.8 \mathrm{ml}$ rabbit Locke. Radioactive ${ }^{14} \mathrm{C}$-mannitol was added as an extracellular space marker. STX binding is determined both in the presence and absence of TTX; the TTX completely inhibits the saturable uptake of tritiated STX; thus the difference between the 2 values gives the saturable uptake. Accordingly, $10 \mu \mathrm{M}$ TTX was added to another identically prepared sample. The samples were incubated in an ice bath with agitation for $5-8 \mathrm{hr}$, after which binding was terminated by blotting and the tissue weighed. The sample was then solubilized in $0.6 \mathrm{ml}$ Protosol (New England Nuclear) at $55-60^{\circ} \mathrm{C}$ and counted in 10 $\mathrm{ml}$ of toluene-POPOP adjusted to $\mathrm{pH} 7$ in a Searle Tricarb scintillation counter. Aliquots from the remaining solution were counted to determine the final STX concentration. Graphs were constructed by pooling data from the individual binding experiments.

Quantitative ventral root histology. A sampling procedure was developed to estimate for each ventral root from all cats (1) the total myelinated fiber count, (2) the axonal perimeters and their distribution, (3) the myelin thickness and its relation to fiber diameter, and (4) the percentage of total root cross-sectional area occupied by endoneurial space. Because of the large number of fibers, a fairly accurate, semiautomated quantitative system was used to assess these parameters.

A short segment of ventral root was obtained near the dura along each root $\mathrm{L} 5, \mathrm{~L} 6, \mathrm{~L} 7$, and $\mathrm{S} 1$. These were immersion-fixed in $1 \%$ paraformaldehyde, $2 \%$ glutaraldehyde, $1 \%$ acrolein, and were then postfixed in $2 \%$ osmium tetroxide, embedded in Poly 812 , sectioned, and stained with a modified Stevenel's stain. A low-power micrograph was taken of the entire section and of a calibration slide at the same magnification to determine cross-sectional area. High-power micrographs (1000$1350 \times$ ) were made of a standardized grid sample area based on a previous pilot study (comprising approximately $13 \%$ of total root area) and calibrated. The perimeter of the entire root and then of the individual fibers (both internal and external) in each sample area were manually traced on a digitizing tablet interfaced to an Apple II + computer. The algorithm employed calculates areas and perimeters based on the trapezoidal rule and the Pythagorian theorem, respectively, and is similar to that reported by Cowan and Wann (1973). The resulting array of fiber and axonal perimeters for each profile encountered in the sample area was then grouped according to size into $1 \mu \mathrm{m}$ bins. A total fiber count based on the fiber density within the sample area(s) and the total cross-sectional area were estimated for the root in question.

An additional animal (the seventh) was used to examine the entire root to control for changes in the total number of fibers (and branches) at various points along the intradural course of the root. This animal (C9) was perfused 42 weeks after surgery, and the axotomized unilateral L6, L7, and S1 ventral roots were fixed, embedded, and sectioned every $3 \mathrm{~mm}$ from the cord exit to the dural junction for serial estimates of total fiber count.

The spinal cord from animal C9 was removed en bloc, fixed, and embedded in paraffin. Ten micron sections were obtained and stained for Nissl with thionin-acetate. Anterior horn cells were counted in every tenth section from the $\$ 1$ and L6 level under low-power light microscopy $(100 \times)$. Only cells with clearly defined processes located ventral to the canal with a central nucleus and a uniform dense nucleolus were enumerated. An estimate of anterior horn cell loss from a proximal cryoaxotomy was then made. The resulting root-fiber per motor neuron ratio would be of interest in the final tally of anterior horn cell sodium channel production due to peripheral injury.

Internodal length measurements. Fascicles not used in binding experiments were fixed with $0.4 \%$ formaldehyde in $0.1 \mathrm{~N}$ phosphate buffer and were then stained with $0.5 \%$ osmium tetroxide in $0.1 \mathrm{~N}$ phosphate at $\mathrm{pH} 7.2$ and stored in diluted glycerol. Single fibers or bundles of $2-$ 3 fibers containing up to 10 internodes were teased from the fascicles. Three diameter measurements were made for each internode and averaged to yield a representative diameter. The internodal lengths from a given cat were all pooled according to fiber diameter in $1 \mu_{\mathrm{M}}$ bins and the mean and SD plotted for each class. No distinction was made between them as to spinal level

Statistical methods. The binding curves were fitied to the equation (Colquhoun et al., 1972)

$$
B_{\text {tot }}=b[\mathrm{STX}]_{f}+B_{\max }[\mathrm{STX}]_{f} /[\mathrm{STX}]_{f}+K_{d}
$$

The slope parameter $b$ was obtained by a linear-regression fit to the binding data obtained in the presence of $10 \mu \mathrm{M}$ TTX. The parameters $B_{\max }$ and $K_{d}$ were obtained using a Marquart rionlinear least-squares algorithm (Bevington, 1969). The fitted binding data incorporated the pooled, single-observation results from several cats with no distinction as to level of origin. A variance estimate for each of the binding points was not feasible. An estimated SD of the fitted parameter $B_{\max }$, as well as a calculated SD for those points above $4 \mathrm{nM}$ STX, was available from which to calculate confidence limits (CL). The more conservative value was always employed. The number of binding sites per node $(X)$ was derived from the ratio of the STX receptor number per milligram of ventral root $\left(C=B_{\max } A_{v}\right)$ to the total nodal number per milligram of ventral root $[N]$.

The representative number of nodes $[N]$ per milligram of operated and of control ventral root was derived using the individual nodal numbers $\left(n_{i}\right)$ calculated for each of the 4 matched roots obtained from the 5 operated cats with a correction for interroot variability. For this purpose, multiple linear regression was performed on the log-transformed values for $n_{i, j, k}[i=$ levels $\mathrm{L} 5, \mathrm{~L} 6, \mathrm{~L} 7, \mathrm{~S} 1 ; j=$ cats $5,7,16,17$, $18 ; k=1$ (regenerated), 0 (control)] to arrive at the coefficients and associated SE that relate the additive effects of each of the isolated variables identified $\left(i, j, k, i k_{1}\right)$ to the predicted value $[N\rceil$. In addition, a factorial analysis of variance tested for significance in the contribution that the various isolated effects made to the total observed variance. These 2 sets of computations were performed on a DEC- 10 computer utilizing the Minitab statistical package (Minitab Project, Pennsylvania State University). Ninety-five percent confidence limits for $[N]$ were calculated from the SE of the coefficients. Finally, Student's $t$ test was used to test the hypothesis that there were no differences between the number of channels per node in normal and regenerated ventral roots.

\section{Results}

\section{Clinical examination}

All 6 cats $(5,7,10,16,17,18)$ displayed a flaccid left leg suspended in a flexed position at the hip in the immediate postoperative period. This included the denervation of all major muscle groups in the distribution of the sciatic, tibialis, and common peroneal nerves (Reinhard and Jennings, 1961). 'The femoral nerve (L5) was moderately involved, and the gluteal nerve appeared to be lcast affected, with carly return in the ability to circumduct the leg. During the next 4 months, 5 animals regained the customary elevated heel posture for locomotion; this indicated reinnervation of the gastrocsoleus muscles, which receive supply from all the levels axotomized (Romanes, 1951). One animal (16) recovered completely by 16 weeks and was sacrificed at $16 \frac{1}{2}$ weeks, at which time the left gastrocsoleus muscle weighed $32.2 \mathrm{gm}$, which was $92 \%$ of the control side. Cat 10 recovered poorly and developed complications and was excluded from the study. The remaining cats had some evidence of residual abnormality on examination at the time of sacrifice $(19,20,45,45$ weeks postop).

\section{Histology}

An example of the cross-sectional histologic appearance from one pair of ventral roots is shown in Figure $1 A$ (control) and $1 B$ (regenerated), from cat 18 (20 weeks) at the L5 level. The normal ventral root histology with a homogeneous fiber size distribution (Bergman and Afif, 1974) is exemplified by Figure $1 A$. The precentage of unmyelinated fibers in the ventral root has been estimated from electron micrographs to be $29 \%$ of the total. They are very small $(0.5 \mu \mathrm{m})$ and originate in the dorsal root ganglion (Coggeshall et al., 1974). Their percentage in re- 
Figure 2. A, Computed fiber-size histogram for $\mathrm{S} 1$ ventral root digitized from a sample light-micrograph area such as in Fig. 1 (cat $17 \mathrm{~S} 1 \mathrm{R}$ at 19 weeks). Axonal perimeter $(\mu \mathrm{m})$ is given along abscissa. The equivalent fiber diameter is the perimeter divided by $(\pi g)$, where $g=d / D=0.63$. P1 and P2 correspond to the bimodal population classes, as shown with diameters of 7-8 $\mu \mathrm{m}$ and $20 \mu \mathrm{m}$, respectively. $B$, Histogram for contralateral axotomized root (S1L). The spectrum is shifted toward smaller perimeters with a predominant "P1" pattern (diameter, $4 \mu \mathrm{m}$ ), although a less populated class of fibers is appreciable at an intermediate size range ("P2"; 14 $\mu \mathrm{m}$ diameter).

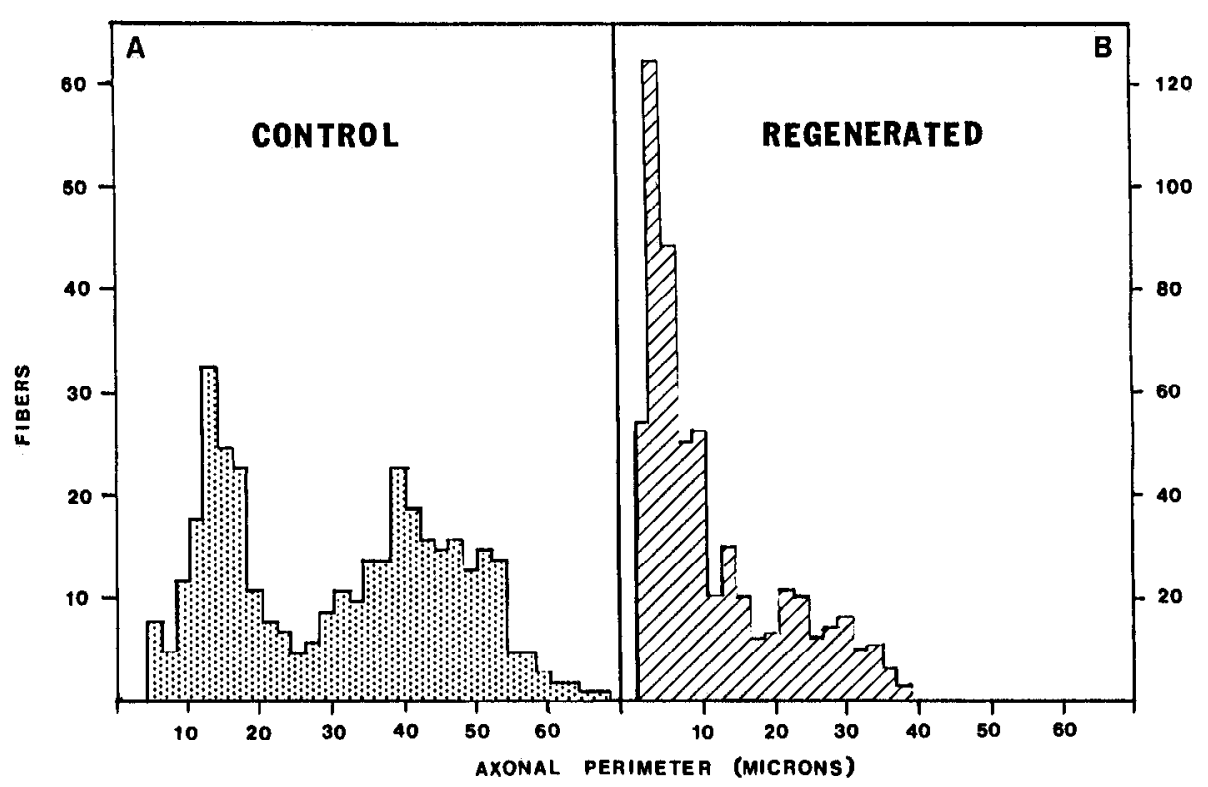

generated ventral roots is not known but is assumed to be unchanged. A correction for their presence was made. Even a substantial change in unmyelinated fibers would have only a minor effect in results.

Figure $1 B$ is a cross section from the contralateral regenerated ventral root. The fibers fall into a smaller, but more dispersed size class. Regeneration and branching are demonstrated, respectively, by noticeably thinner myelin sheaths, and occasional groupings of several small profiles enclosed within 1 sheath, a so-called band of Bungner (Guth, 1956; Allt, 1976).

The fiber-size histogram in Figure 2 is representative of the root pairs analyzed in this series. The control root axonal sizes have a bimodal distribution that is characteristic of motor nerves (Shawe, 1955; Sjöstrand et al., 1969). The regenerated fibers are predominantly grouped into a small-caliber class but also reveal a discernible second population of intermediatc-sized fibcrs, consistent with restoration of bimodality (Sjöstrand et al., 1969; Thulin and Carlsson, 1969). The histologic parameters obtained for all 4 root pairs of 1 cat (17) are summarized in Table 1 . The mean value of $g=0.63$ (axon/fiber diameter) in the far-right column did not differ between the control and regenerated populations, and this is taken as evidence for mature remyelination.

In Table 1, the cross-sectional area of the regenerated root proper has diminished in most instances by around $36 \%$. The length/weight ratio also decreased but by a smaller amount. The percentage of extracellular (or endoneurial) space in all regenerated roots had increased by approximately $20-30 \%$; however, only a slight increase in extracellular fluid per milligram wet weight was obtained using the extracellular space marker. Similar absolute endoneurial compartment size and greater fascicle density from connective tissue proliferation in the regenerated ences in blotting or marker penetration.

The estimated total numbers of fibers in each ventral root from representative cat 17 are also listed in Table 1. For control roots, the numbers ranged from 3300 to 5600 , comparable with values from other studies of feline ventral roots (Sjöstrand et al., 1969; Berthold, 1978). In the regenerated roots, the total fiber counts increased from 10 to $70 \%$ (average, 1.45 -fold). Acknowledging an unknown percentage of anterior horn cell droproots account for the apparent discrepancy better than differ-

Table 1. Summary of the parameters obtained from the morphology gathering program for 1 operated cat (17)

\begin{tabular}{|c|c|c|c|c|c|c|c|c|c|c|c|}
\hline \multirow[b]{2}{*}{ Level } & \multirow{2}{*}{$\begin{array}{l}\text { Nerve } \\
\text { Area } \\
\left(\mathrm{mm}^{2}\right)\end{array}$} & \multirow{2}{*}{$\begin{array}{l}\text { Area } \\
\text { sampled } \\
(\%)\end{array}$} & \multirow{2}{*}{$\begin{array}{l}\begin{array}{l}\text { Length } \\
(\mathrm{mm})\end{array} \\
\text { Weight } \\
(\mathrm{mg})\end{array}$} & \multirow{2}{*}{$\begin{array}{l}\text { ECS } \\
(\%)\end{array}$} & \multirow{2}{*}{$\begin{array}{l}\text { Est. } \\
\text { total } \\
\text { fibers }\end{array}$} & \multirow{2}{*}{$\begin{array}{l}\text { In- } \\
\text { crease } \\
(\%)\end{array}$} & \multicolumn{2}{|l|}{$\mathrm{P} 1$} & \multicolumn{2}{|l|}{$\mathrm{P} 2$} & \multirow{2}{*}{$\begin{array}{l}\text { Int./ext } \\
\text { diam- } \\
\text { eter, } \\
g=\mathrm{d} / 0\end{array}$} \\
\hline & & & & & & & $\operatorname{MAP}(\mu)$ & $\%$ & $\operatorname{MAP}(\mu)$ & $\%$ & \\
\hline L5R & 0.75 & 13.0 & 1.25 & 30 & 3316 & - & 12.2 & 55 & 45.9 & 45 & 0.64 \\
\hline $\mathrm{L}^{5} \mathrm{~L}^{a}$ & 0.47 & 13.1 & 1.22 & 52 & 5406 & 60 & 9.1 & 83 & 34.3 & 17 & 0.63 \\
\hline L6R & 1.09 & 9.3 & 0.75 & 35 & 4370 & & 11.2 & 52 & 40.4 & 48 & 0.59 \\
\hline $\mathbf{L}^{6} \mathrm{~L}^{a}$ & 0.60 & 10.0 & 0.69 & 57 & 6126 & 40 & 7.7 & 50 & 22.8 & 50 & 0.60 \\
\hline L7R & 1.53 & 10.1 & 0.63 & 36 & 5672 & & 12.5 & 47 & 43.7 & 53 & 0.63 \\
\hline $\mathbf{L} 7 \mathrm{~L}^{a}$ & 1.05 & 7.1 & 0.45 & 76 & 6499 & 10 & 10.3 & 76 & 27.3 & 24 & 0.65 \\
\hline S1R & 0.99 & 8.1 & 0.72 & 31 & 4569 & & 14.4 & 42 & 42.8 & 58 & 0.69 \\
\hline $\mathrm{S} 1 \mathrm{~L}^{a}$ & 1.35 & 7.5 & 0.65 & 80 & 7742 & 70 & 7.9 & 76 & 27.2 & 24 & 0.61 \\
\hline
\end{tabular}

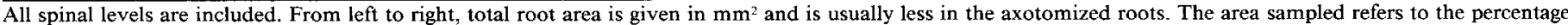

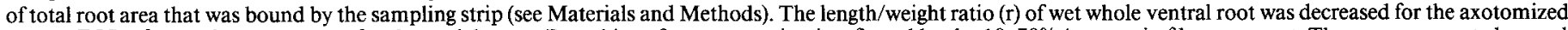

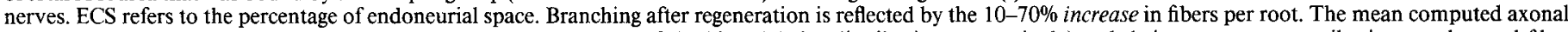

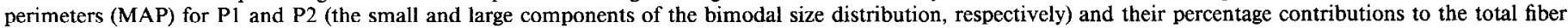
pool are also tabulated.

${ }^{a}$ Regenerated. 


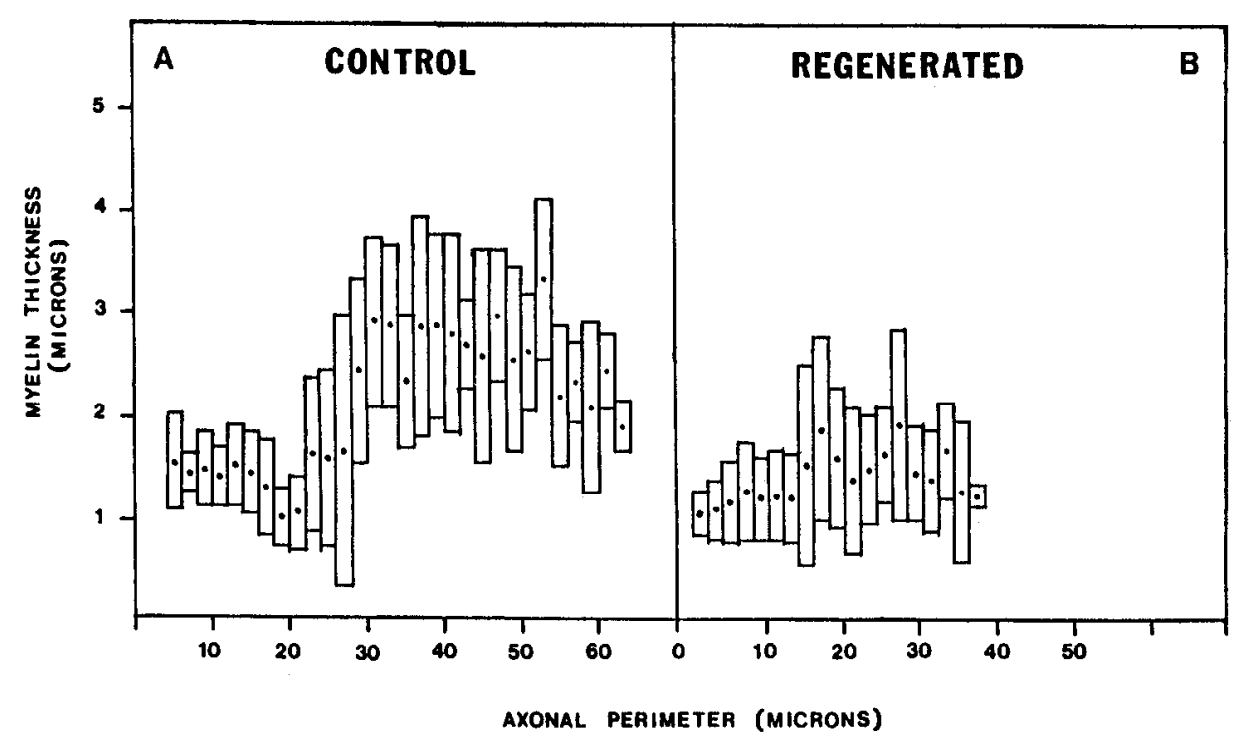

Figure 3. $A$, Computed graphic relationship between axonal size and myelin thickness for control ventral root at 19 weeks (SIR; cat 17). A discontinuous jump at $30 \mu \mathrm{m}$ perimeter is apparent, corresponding to the transition between $\mathrm{P} 1$ an $\mathrm{P} 2$ (see Fig. $7 A$ ). $B$, Contralateral regenerated ventral root (S1L) maintains a fairly constant myelin thickness over all size classes. Means \pm 1 SD are shown. out, this clearly represents branching of the remaining fibers. Distal grafts have been reported to have 1.42 times the number of myelinated fibers in the central stump (Sunderland and Lavarack, 1953). A detailed serial morphologic examination in another operated animal (C9) provided additional evidence justifying the use of cross section for total fiber counts obtained from the far distal portion of the root as representative of the whole root distal to the lesion site. Including all level pairs and cats $(N=19)$, the operated roots have $1.35 \pm 0.52$ times the number of myelinated fibers as do control ventral root.

Anterior horn cell counts were made from serial sections at $100 \mu \mathrm{m}$ intervals at 2 spinal levels from cat C9. A total of 1181 cells was identified. The largest neurons $(40-60 \mu \mathrm{m})$, which reside in the large latcral nuclci, wcre noticeably reduced in number by the axotomy on that side. These cells form the bulk of lumbosacral motor efferents (Romanes, 1951). Neurons found

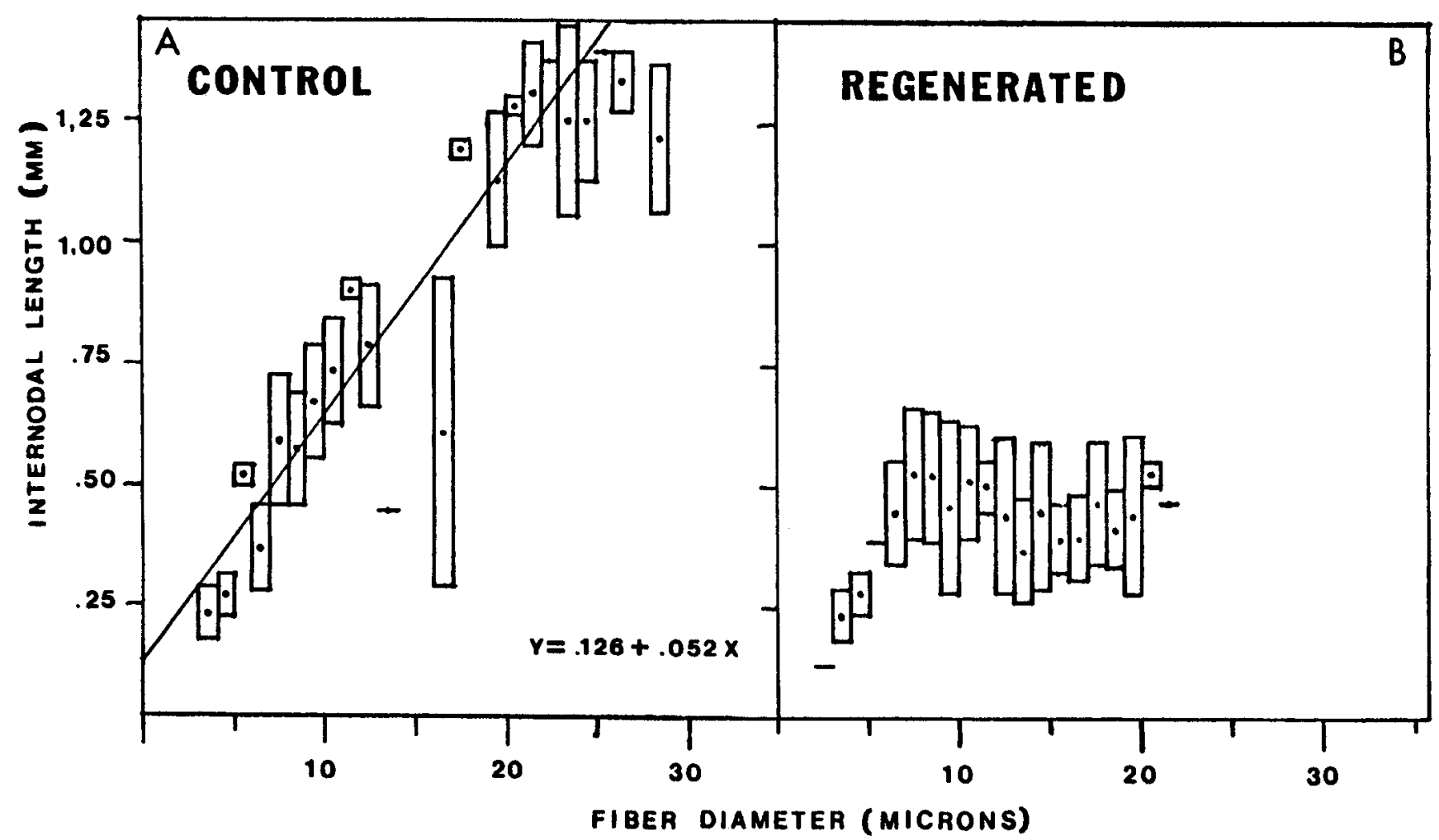

Figure 4. A, Internodal length-fiber diameter relationship for the S1R and L7R control side lumbosacral motor roots from cat 5 at 45 weeks. Note that internodal length is in millimeters, whereas fiber diameter is in microns. The data represents the mean of all pooled single internodes within each $2 \mu \mathrm{m}$ bin size class $\pm 1 \mathrm{SD}$. The least-squares fit is drawn and the resulting relationship given along the lower-right margin. A total of 125 internodes were enumerated. B, Contralateral L5L, L6L, and S1L axotomized fibers from cat 5 . A total of 231 internodes were entered. Note the uniform nodal spacing across size classes $>8 \mu \mathrm{m}$. 
Table 2. Summary of nodal calculations given as number per mg nerve ( $r$ ) for all ventral roots (top) and all cats (left) entered in the study

\begin{tabular}{|c|c|c|c|c|c|c|c|c|}
\hline \multirow[b]{2}{*}{ Cat } & \multicolumn{4}{|c|}{ Control } & \multicolumn{4}{|c|}{ Operated (left hemilaminectomy) } \\
\hline & L5 & L6 & L7 & S1 & L5 & L6 & L7 & S1 \\
\hline \multicolumn{9}{|l|}{6} \\
\hline Right & 4628 & 4809 & 3845 & 11,193 & & & & \\
\hline Left & 3574 & 5478 & 4113 & 8739 & & & & \\
\hline 17 & 4870 & 3957 & 4002 & 3510 & 18,111 & 10,953 & 7910 & 13,614 \\
\hline 16 & & 4326 & 5399 & 6114 & & 11,252 & 10,550 & 11,273 \\
\hline 5 & & & 5355 & 8114 & & & 6668 & 36,923 \\
\hline 7 & 3598 & 3309 & & & 12,896 & 3987 & & \\
\hline 18 & 4414 & 4584 & & & 13,089 & 8952 & & \\
\hline Mean & \multicolumn{4}{|c|}{$\bar{n}=5139 \pm 1973$} & \multicolumn{4}{|c|}{$\bar{n}=12,783 \pm 8052(2.5 \times)$} \\
\hline
\end{tabular}

A 2.5-fold increase in mean, uncorrected nodal number $(\bar{n})$ is calculated for the axotomized roots. The formula used for calculation of nodal number is given below. Multiple linear regression and analysis of variance was performed on the data to derive the coefficients for the expected nodal number $[N]$ and to determine the relative contribution of several variables to the total observed variance, respectively. Variance effects between right and left in the control animal, between the operated cats, and between spinal level $\times$ axotomy were not significant. The effect of axotomy and subsequent regeneration was the most significant contributor to the total variance $(p<0.0001)$. The $\mathrm{S} 1$ level was responsible for a significant degree of between-levels variance $(p<0.05)$.

Formula for calculating nodal number:

$$
n_{i, j, k}=r \int_{D=0}^{\infty} m I^{-1} d D \simeq r\left(m_{1} / I_{1}+m_{2} / I_{2}\right)
$$

where $r$ is $\mathrm{mm} / \mathrm{mg}$ (wet weight), $D$ is equivalent fiber diameter (= axon perimeter $/ \pi g$, where $g$ is int/ext), $I$ is internodal length [ $=f(D)], m$ is the estimated contribution to total fiber number in root made within a given fiber size increment.

in the medial motor nuclei were smaller in size $(10-30 \mu \mathrm{m})$ and relatively less affected in number by the unilateral surgery. Some of these may even belong to a class of spinothalamic neurons (Willis and Coggeshall, 1978), which may partially explain their immunity from the postchromatolytic necrosis undoubtedly experienced by the larger nuclear group. They were included in the counts nevertheless. The hemiventral horn whose axons were interrupted suffered a $35 \%$ (S1) to $36 \%$ (L6) loss in motor neuron number.

In Figure 3, the relationship between myelin thickness and axonal size is presented for control and regenerated ventral roots from the same cat. P1 has myelin that is about $1.5 \mu \mathrm{m}$ thick, whereas $\mathrm{P} 2$ myelin is $2.5-3 \mu \mathrm{m}$ thick. A minority of regenerated fibers, $>30 \mu \mathrm{m}$ in size, had relatively thinner myelin sheaths. Single fibers were teased from all 4 levels (right and left) of each cat and assessed for internodal lengths and mean fiber diameter. The results are plotted for cat 5 ( 45 weeks) in Figures $4 A$ (control) and $4 B$ (regenerated). The line drawn through the control points is a linear least-squares fit; however, a curvilinear relationship with an asymptote at large fiber diameters might describe the data as well. The literature supports both interpretations (Hursh, 1939; Schnepp and Schnepp, 1971; Fried et al., 1982). The regenerated fibers had, as anticipated from the introduction, diminished but constant internodal lengths, especially for fibers greater than $8 \mu \mathrm{m}$. This is taken as evidence for the completeness of the lesion and the universality of the regenerative process (Hiscoe, 1947; Vizoso and Young, 1948).

The total number of nodes of Ranvier per milligram of each individual ventral root can be calculated (Table 2) from the length/weight ratios, total number, and size distribution of myelinated fibers within each ventral root and their respective internodal lengths. The calculated mean number $(\bar{n})$ of such nodes for control and operated roots indicated at Table 2 (bottom) is, however, skewed. The analysis of variance demonstrated that the S1 level was responsible for the large variance $(p<0.05)$.
Perhaps its smaller diameter fibers conferred upon it smaller nodal spacing and hence more nodes. The expected value derived from the regression analysis for the pooled nodal number incorporated a correction factor for the $\mathrm{S} 1$ effect based on its net weight contribution. The final result $[\mathrm{N}]$ was that for control and normal ventral roots there are expected to be 4629 (3435, $6475: 95 \% \mathrm{CL}$ ) nodes/mg and for the axotomized group a total of $10,963(7935,16,056: 95 \% \mathrm{CL})$ nodes $/ \mathrm{mg}$. This represents a 2.36 -fold increase over the untreated roots and is highly significant.

\section{${ }^{3} \mathrm{H}$-STX binding}

The ${ }^{3} \mathrm{H}-\mathrm{STX}$ binding results in the control ventral roots from all 5 operated animals are given in Figure 5 . The fitted results are $B_{\max }=10.2 \pm 0.4 \mathrm{fmol} / \mathrm{mg}$ wet, $K_{d}=0.55 \pm 0.12 \mathrm{nM}^{-1}, b$ (linear slope) $=1.34 \mathrm{fml} / \mathrm{mg} \cdot \mathrm{nm}$. The SD of the fit was 3.67 $\mathrm{fmol} / \mathrm{mg}$ and the coefficient of determination, which reflects the "goodness" of fit, was 0.92 (Nettler and Wasserman, 1974). The fitted coefficient for $B_{\max }$ from the specific binding data was 10.8 $\mathrm{fmol} / \mathrm{mg}$. The maximal binding results are in agreement with those from 2 normal unoperated cats $(11.6 \pm 1.4 \mathrm{fmol} / \mathrm{mg}$ ) (Fig. $6, A, B)$. The binding to dorsal roots was higher at $38.4 \mathrm{fmol} /$ $\mathrm{mg}$ (unpublished observation).

The data for the contralateral regenerated ventral roots are plotted in Figure $7 \mathrm{~A}$. The fitting parameters are now $B_{\max }=$ $36.1 \pm 0.46, K_{d}=0.45 \pm 0.4, b=1.34$. The fit SD and coefficient are, respectivcly, $7.99 \mathrm{fmol} / \mathrm{mg}$ and 0.88 . The scatter in the data reflects the inhomogeneities in (1) the length/weight relationship as a result of fibrosis, (2) toxin equilibration, (3) differential response among root levels, or (4) binding to a variable population of non-neuronal elements. It reflects a clearly significant $(p<0.01)$ 3.54-fold increase in STX receptor number per milligram of mature regenerated ventral root over the contralateral control group. The maximal binding observed in the operated ventral roots was unafferted by the duration of regeneration 


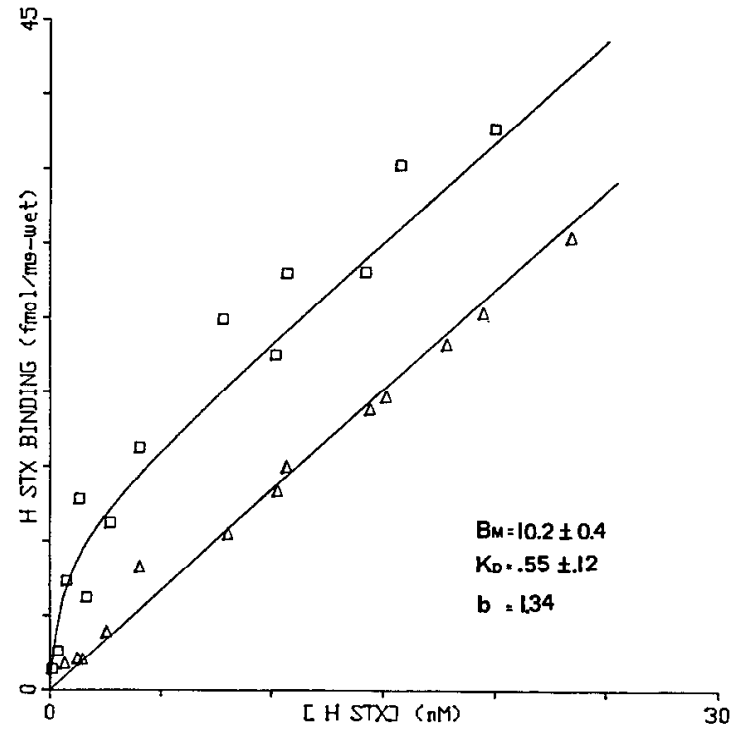

Figure 5. A, ${ }^{3} \mathrm{H}-\mathrm{STX}$ uptake data to the control ventral roots (L5-S1) from all 5 operated animals expressed as $10^{-15} \mathrm{~mol} / \mathrm{mg}$ wet weight of mixcd ventral root fascicle (ordinate). The total binding (upper curve) and nonspecific binding (lower line) in the presence of 1000-fold excess TTX $(10 \mu \mathrm{M})$ are shown as a function of the final STX concentration (abscissa). The total binding data was fitted (see text) to the form $B_{\text {tot }}=$ $b[\mathrm{H}-\mathrm{STX}]+B_{\max }[\mathrm{H}-\mathrm{STX}] /[\mathrm{H}-\mathrm{STX}]+K_{d}$, where $b$ is the slope of the nonspecific binding data calculated by linear least-squares method. Each point represents 1 experiment. The fitted parameters are given.

between 16 and 45 weeks. The saturable binding for both the regenerated and control plus normal ventral roots is plotted together in Figure $7 B$ for comparison. The aflinity constant for ${ }^{3} \mathrm{H}-\mathrm{STX}$ has not changed in the newly formed receptors.

To calculate the number of channels per node of Ranvier, it was necessary to multiply the fitting parameter $B_{\max }(\mathrm{fmol} / \mathrm{mg})$ by Avogadro's number $\left(N_{\mathrm{A}}\right)$, after the small correction for unmyelinated fiber binding. This numerator $(C)$ divided by the expected nodal number per milligram $[N]$ yields the final answer $(X)$ and $95 \%$ confidence limits as follows:

$$
\text { Control: } \begin{aligned}
\left(10.2 \pm 0.5 \mathrm{fmol} / \mathrm{mg} \times N_{\mathrm{A}}\right) / 4629 \text { nodes } / \mathrm{mg}= \\
1.26 \times 10^{6} \mathrm{STX} \text { receptors } / \text { node }[0.79,2.02]
\end{aligned}
$$

Regenerated: $\left(36.1 \pm 0.5 \mathrm{fmol} / \mathrm{mg} \times N_{\mathrm{A}}\right) / 10,963$ nodes $/ \mathrm{mg}=$ $1.95 \times 10^{6} \mathrm{STX}$ receptors/node $[1.31,3.07]$

The control binding is very similar to the value obtained from other normal cats $\left(1.22 \times 10^{6}\right)$ (unpublished observation). There appear to be 1.54 times as many STX receptors in the newly formed nodes.

It will be noted that the confidence intervals overlap. Twotailed hypothesis testing concluded that the difference in STX receptors per node observed between control and regenerated ventral roots did not reach significance $(p>0.10)$.

\section{Discussion}

The various sodium channel and STX binding parameters reported for normal unmyelinated and myelinated nerve fibers using several different methods are summarized in Table 3. Sodium channel density estimates as given by ${ }^{3} \mathrm{H}-\mathrm{STX}$ binding and electrophysiological methods are in excellent agreement for unmyelinated squid axons. Even in frog node, ${ }^{3} \mathrm{H}-\mathrm{STX}$ receptor number is well within an order of magnitude range of channel estimates. For mammalian fibers of the same species, however, there is a trend toward higher ${ }^{3} \mathrm{H}-\mathrm{STX}$ binding per node than the analyses of sodium channel currents would predict. Our estimate of $1.22 \times 10^{6}$ STX binding sites per node for normal cat ventral root is 1.7 -fold greater than that reported for rabbit
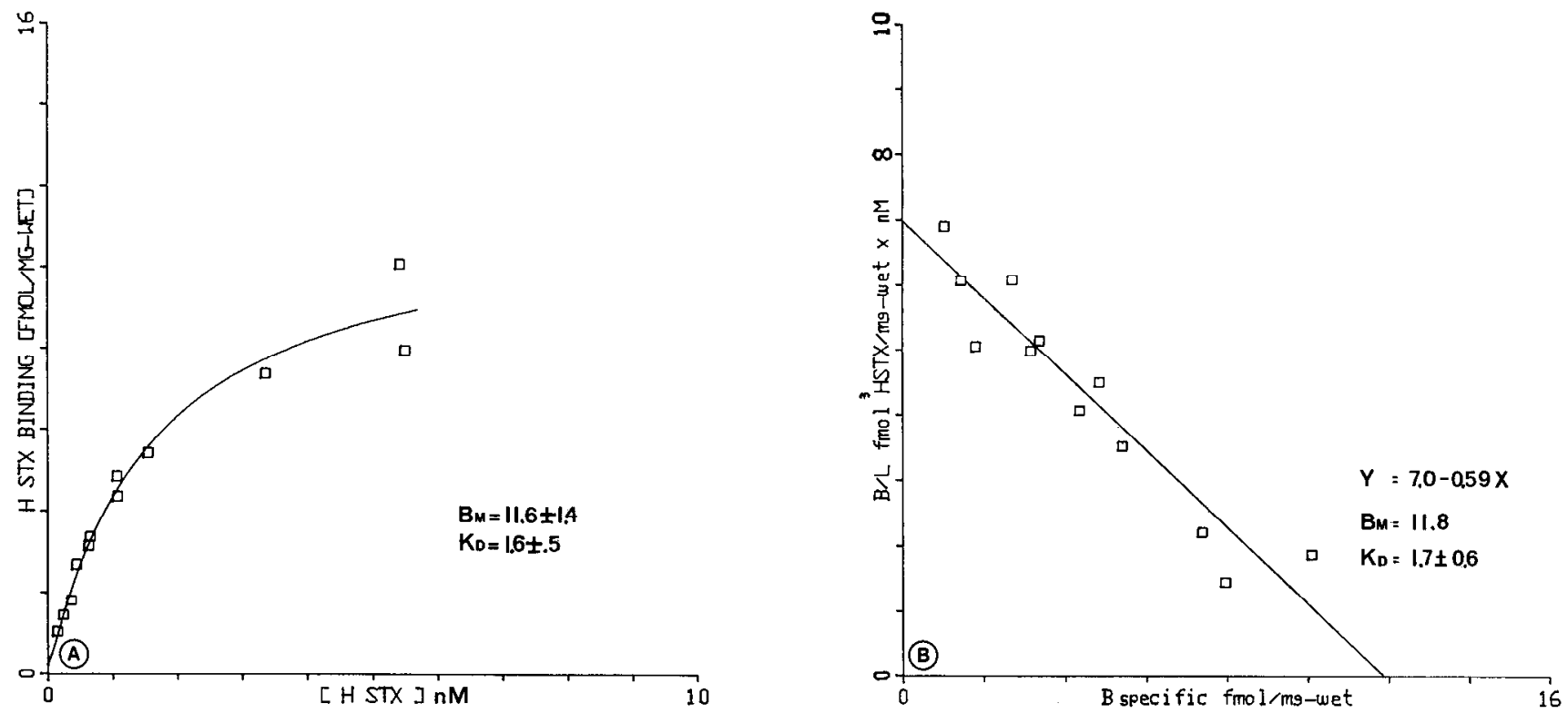

Figure 6. ${ }^{3} \mathrm{H}-\mathrm{STX}$ binding to unoperated feline L7 ventral root segments. Four L7 ventral ronts from 2 cats C6, C7 were divided into equal segments of $5 \mathrm{mg}$ each and treated as in Figure 5 except at concentrations below saturation. $A$, Specific binding data with fitted curve and parameters. $B$, Scatchard plot of same data fitted by linear least-squares method. A higher $K_{d}$ value is noted for pure $\mathrm{L} 7$ fascicles compared with mixed control fascicles from a larger series of operated cats. The small difference in affinity, due possibly to differences in toxin batch, tissue source, and handling, did not affect $B_{\max }$. 
Table 3. Summary table of sodium channel estimates by the various methods

\begin{tabular}{|c|c|c|c|c|c|c|c|}
\hline \multirow[b]{3}{*}{ Model } & \multirow{2}{*}{\multicolumn{3}{|c|}{${ }^{3} \mathrm{H}-\mathrm{STX}$ equilibrium binding }} & \multicolumn{3}{|c|}{$Q_{\max } / \mathrm{N}$ gating currents } & \multirow{3}{*}{$\begin{array}{l}\text { Current } \\
\text { variance } \\
\text { Channels/node }\end{array}$} \\
\hline & & & & \multirow{2}{*}{$\begin{array}{l}\text { Channels/ } \\
\text { node }\end{array}$} & \multirow{2}{*}{$\begin{array}{l}\text { Channels/ } \\
\mu \mathrm{m}^{2}\end{array}$} & \multirow[b]{2}{*}{$\bar{G} N a$} & \\
\hline & Sites/node & Sites $/ \mu \mathrm{m}^{2}$ & $K_{d}$ & & & & \\
\hline Rabbit vagus & & 110 & $1.8^{a}$ & & & & \\
\hline \multicolumn{8}{|l|}{ Loltgo } \\
\hline \multirow[t]{2}{*}{ forbesi } & & $553 \pm 120^{b}$ & & & 483 & $1.2 \mathrm{nS} / \mu \mathrm{m}^{2 d, k}$ & \\
\hline & & $522-324^{c}$ & & & $200-300^{\prime}$ & & \\
\hline pealei & & $166 \pm 20$ & $4.3^{d}$ & & & & \\
\hline Frog node & 132,000 & $2000^{c e}$ & $5.3^{r g}$ & 246,000 & $5212^{s}$ & $\begin{array}{l}15-20 \mathrm{nS} / \mu \mathrm{m}^{2 m} \\
(0.57-0.97 \mu \mathrm{S})\end{array}$ & 34,400 \\
\hline Cat node & $1.22 \times 10^{6}$ & $18.5 \times 10^{3}$ & $1.6^{n}$ & & & $0.36 \mu \mathrm{S}^{n}$ & \\
\hline Rabbit node & 720,000 & $10-12 \times 10^{3 e}$ & $3.3^{f i}$ & 82,000 & & $0.22-0.76 \mu \mathbf{S}^{n . o}$ & \\
\hline
\end{tabular}

Rat node

(2.3 $\times$ increase in binding/unit length;

Remeylinated rabbit

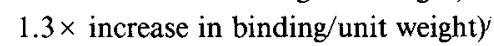

The various preparations (models) employed are listed at left. The values obtained for a particular method are subdivided into relevant parameters. $\bar{G}_{\mathrm{Na}}$ is maximal nodal sodium conductance. $\gamma$ is the single-channel conductance.

"Ritchie et al. (1976).

${ }^{b}$ Levinson (1975).

' Keynes et al. (1975): from kinetics.

${ }^{d}$ Strichartz et al. (1979).

e Nodal area taken to be $66 \mu \mathrm{m}^{2}$.

f Ritchie (1978).

${ }^{g}$ Ritchie (1979)

" This study.

i Ritchie and Rogart (1977a).

'Ritchie et al. (1981). Conditions: lysolecithinized, homogenized, 5 nм STX, 2 months recovery.
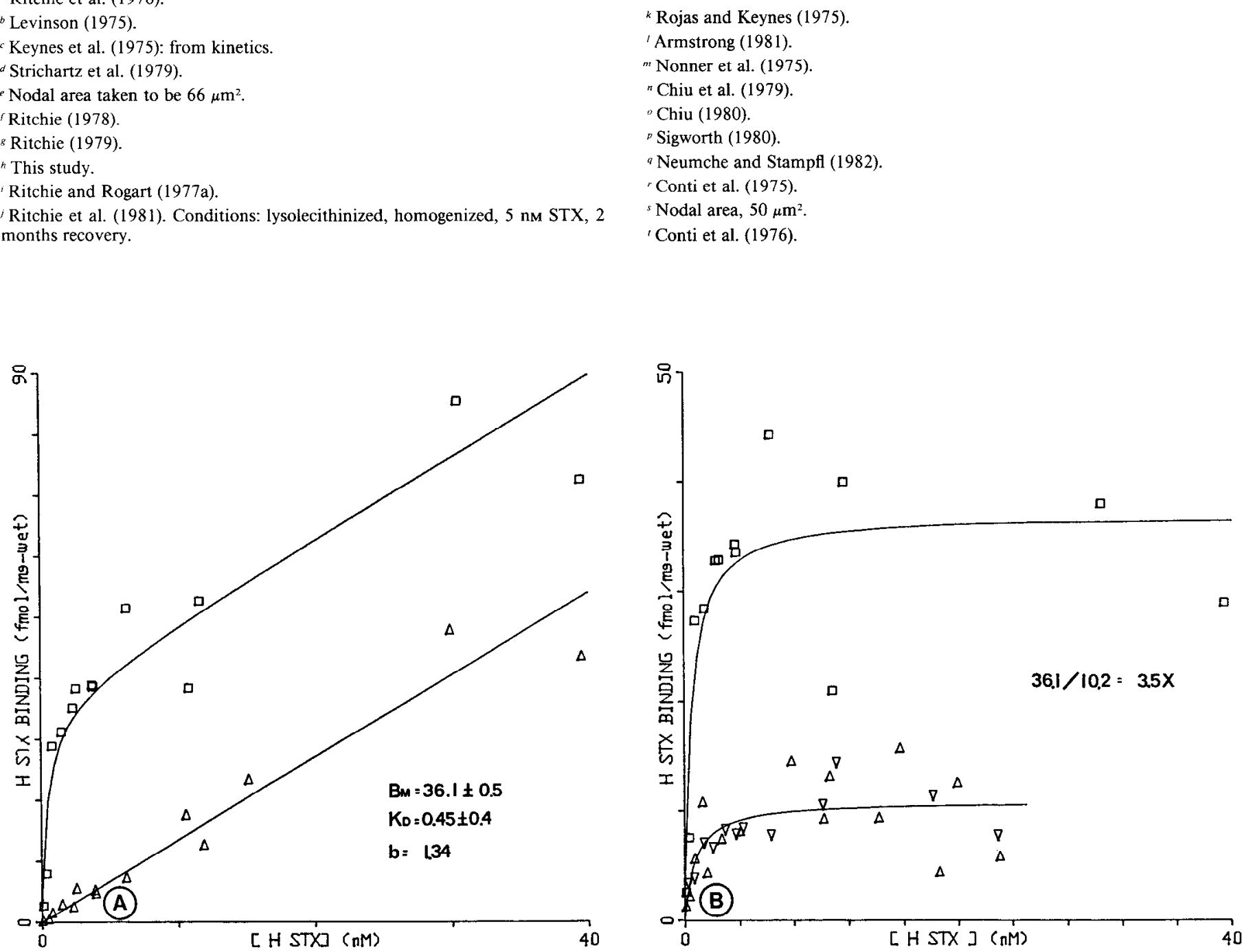

Figure 7. A, ${ }^{3} \mathrm{H}-\mathrm{SIX}$ uptake by the contralateral regenerated ventral lumbosacral roots to those shown in Figure 5. Same 5 cats (16-45 weeks). Each point represents 1 experiment. Note difference in ordinate scale. The maximal binding from the fit is 36.1 ( $3.5 \times$ greater than control); however,

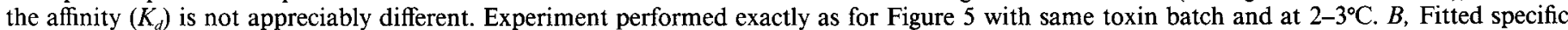
binding for axotomized (upper) and contralateral (lower) control ventral roots plotted together for comparison. The maximal binding ratio is given along at right. The extra points included with the lower curve (controls) are data taken from a series of unoperated cats. 
Table 3. Extended

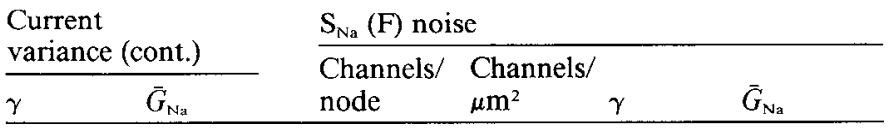

330

$\begin{array}{llllll}6.4 \mathrm{pS} & 0.22 \mu \mathrm{S}^{\rho} & 100,000 & 2000^{s} & 6.8 \mathrm{pS} & 0.683 \mu \mathrm{S}^{t}\end{array}$

$14.5 \mathrm{pS}^{q}$

sciatic nerve using the same technique (Ritchie and Rogart, 1977a; and see Table 3); however, confidence limits were not given for the latter. Although our value of $B_{\max }$ is only $50 \%$ of that reported by Ritchie and Rogart (1977a) and Ritchie (1978), the larger receptor/node ratio results from a relatively smaller nodal number per milligram of feline nerve, which is only 4985 as compared with 14,200 in the rabbit sciatic ncrvc. Interspccics differences and differences in myelinated fiber size distributions between ventral root and sciatic nerve and, therefore, nodal spacing probably account for this observation (Yates et al., 1976). In addition, larger-diameter fibers, as those in the cat, may have a larger nodal area and more channels per average node than in rabbit. A tendency for larger-diameter fibers to have a higher peak $I_{\mathrm{Na}}$ and maximal conductance has been noted (Table 3 in Nonner et al., 1975; Chiu, 1980; Table 1 in Sigworth, 1980). Furthermore, it is not likely that our relatively high receptor/ node estimate is attributable to an inflated $B_{\max }$ because a value of $37.1 \pm 4.3 \mathrm{fmol} / \mathrm{mg}$ has been reported for cat sciatic nerve (Waxman and Ritchie, 1981). The latter $B_{\max }$ is understandably large, as sensory fibers probably account for a greater proportion of binding in mixed nerve than do motor fibers (see STX binding results).

The large number per feline node that we report, nonetheless, remains plausible after consideration of steric restraints. Dividing our receptor number by nodal areas of 36 and $107 \mu \mathrm{m}^{3}$, corresponding to the bimodal fiber clases, a receptor density of $18,500 / \mu \mathrm{m}^{2}$ is obtained. If the diameter of a sodium channel is approximated to that of the isolated TTX binding polypeptide, $5 \mu \mathrm{m}$ (Miller et al., 1982), we calculate a 36\% nodal areal occupancy by STX receptors. A $60 \%$ occupancy was estimated by Ritchie and Rogart (1977a). The use of Berthold's (1968) values for nodal areas corresponding to P1 $\left(4 \mu \mathrm{m}^{2}\right)$ and P2 $\left(20 \mu \mathrm{m}^{2}\right)$, in accordance with a $50 \%$ axonal constriction of the node, would increase both reported densities an additional 5-fold.

This study confirms the trend of higher receptor than channel density reported in mammals and again raises the issue of whether all the observed STX binding is indeed to nodal sodium channels or if the additional difference is accountable by some other phenomenon.

The possible absence of a 1:1 STX binding site and sodium channel stoichiometry has been reviewed by Catterall et al. (1980) and has been offered as a possible explanation. Glial binding of STX may account for a portion of the discrepancy as demonstrated by TTX sensitive depolarization and ${ }^{22} \mathrm{Na}$ influx (Villegas et al., 1976; Lazdunski et al., 1980) and residual STX binding months after proximal nerve ligation (Ritchie et al., 1981; Ritchie and Rang, 1983). Such binding may have both specific and nonspecific components and if present to a very large extent, especially in regenerated nerves, could pose significant limitations on the interpretation of our results. Shrager et al. (1985) have suggested that Schwann cells may be involved in the manufacture of sodium channels for insertion into the axolemma based on their findings of voltage-sensitive currents and saturable ${ }^{3} \mathrm{H}-\mathrm{STX}$ uptake in cultured cells. They calculate 25,000 STX sites (but only 920 channels) per rabbit Schwann cell. At a ratio of one such cell per node, the glial contribution to the observed binding for normal rabbit nerve would amount to only $3.5 \%$. This alone would not account for the discrepancy between receptor and channel estimates in mammalian nerves. Unless it can be shown that feline Schwann cells bind 10-fold more STX than do rabbit Schwann cells, there are no compelling reasons to suspect a significant glial contribution to the total binding in normal cat.

In our regenerated nerves, there is a 2.36 -fold increase in nodes and at least this degree of Schwann cell proliferation as well. The total binding contribution made by the latter could therefore be slightly greater. It would be substantial if regenerated Schwann cells possessed more receptors than normal glial cclls. STX binding on the order of $32 \mathrm{fmol} / \mathrm{mg}$ wet weight of in vitro cultured Schwann cells (Shrager et al., 1985) and $40 \mathrm{fmol} /$ mg wet weight of in vivo preparations of Schwann cells in degenerated distal stumps (Ritchie and Rang, 1983) may seem large, but these preparations lack viable axons and myelin. The contribution by glial soma and paranodal processes to the wet weight and receptor number in our roots is not known; however, we feel that conclusions can be drawn even when STX binding customarily assigned to nodal axolemma excludes a correction for an unknown, but probably less significant, Schwann cell factor.

Ritchie et al. (1981) studied changes in sodium channel number in peripheral nerve that had undergone remyelination following lysolecithin demyelination. By $50 \mathrm{~d}$ after injection in the rat sciatic nerve, the authors noted that at least $70 \%$ of the fibers were thinly myelinated and that a $25 \mathrm{~mm}$ length of homogenized nerve including the lesion site bound 1.3 times as much ${ }^{3} \mathbf{H}$ $\mathrm{STX} / \mathrm{mg}$ or 2.3 times $/ \mathrm{mm}$ when compared with control (Table 1). By $200 \mathrm{~d}$, the corresponding figures were 1.9 and 2.7 times normal. These increases are similar to the increase reported here. Although quantitative morphology and adjustment for binding to sensory fibers was not performed, Ritchie et al. offered the interpretation that the number of channels per node remains constant in remyelinated nerve.

Our results based on axotomized nerve primarily demonstrate that, despite a substantial increase in the number of nodes in regenerated axons, the number of STX receptors associated per node does not decrease and may even increase slightly. There is a roughly 6.2-fold increase in receptors per neuron. This result is the product of a 1.54-fold increase in receptors per node, an average 1.94-fold increase in nodes per fiber, and a 1.35-fold increase in fibers (branches of surviving axons) accompanied by a $35 \%$ reduction in anterior horn cells. This is expected to put an increased metabolic load on the regenerated neuron that 
would include the supply of additional membrane channels and other structural components (Griffin et al., 1981; Parhad et al., 1982). Since the amount of sodium influx per impulse is almost directly proportional to the number of sodium channels, there would be an additional increased demand on the sodium-potassium pump that must maintain the ionic gradients necessary for conduction. This in turn produces an increase in demand for oxidative metabolism and, presumably, a requirement for more mitochondria. The smaller axoplasmic volume combined with the increase in sodium flux might also result in more rapid accumulation of intracellular sodium and loss of potassium. Thus, the energy reserve for conduction (in the form of the ionic gradient) of the regenerated fibers could be substantially reduced under special conditions, such as sustained high-frequency impulse trains. Nevertheless, reorganization in response to injury may serve to reduce impedance mismatch and thus increase the safety factor for transmission at the junction of myelinated and demyelinated axonal segments (Waxman and Brill, 1978).

The current study has significant implications for the mechanism of channel reorganization in demyelination and remyelination. Our results strongly suggest that redistribution of existing channels is not the sole manner by which new nodes become excitable. They are more consistent with the synthesis of ncw channels and their incorporation into the axolcmma proportional to the rise in nodal number. This adaptation occurs over a fairly long period and may not be applicable in the acute setting. Computer simulations of conduction suggest that only $4 \%$ of the nodal density of channels needs to be present in a demyelinated area to sustain continuous conduction. Hence, according to Waxman's (1978) estimate, redistribution of preexisting channels may be all that is required in an acute segmental demyelination. However, diffusion of nodal sodium channels over the entire cat internode without new synthesis would lead to a channel density $0.2 \%$ of that in the node or about 36 channels $/ \mu \mathrm{m}^{2}$, which appears to be insufficient to sustain continuous conduction. Limited diffusion of channels in the very acute stages of injury probably does occur since ferric ion-ferrocyanide staining is noted to spread from the nodal confines as early as $1 \mathrm{hr}$ after application of antigalactocerebroside serum (Saida et al., 1980).

In acutely disrupted mammalian paranodes, the total sodium current does not change-which is inconsistent with rapid new synthesis and insertion of channels but not with limited diffusion (Chiu and Ritchie, 1982). Evidence from external longitudinal current recordings for continuous conduction in demyelinated and myelinated spinal fibers (Bostock and Sears, 1976; Rasminsky and Kearney, 1976) is consistent with either new channel synthesis and nondiscontinuous insertion, diffusion of preexistent channels, or technically limited spatial resolution.

The possibility of significant sodium channel synthesis and STX receptor binding in regenerating nerves by proliferating Schwann cells (in addition to those supplied by the perikaryon to the nodal axolemma) is a theoretical one, but the numbers are not convincing. Furthermore, the appearance of "phi nodes" in demyelinated rat ventral roots appears to be independent of Schwann cell differentiation, nodal register, or inactivation by irradiation (Smith et al., 1982; see also Feasby et al., 1981, and Oaklander et al., 1984). An understanding of the factors controlling the synthesis and redistribution of sodium channels following injury could lead to more effective treatment of demyelinating diseases.

\section{Conclusion}

In response to axotomy and regeneration in cat ventral roots, the following responses occur:

1. A 1.35-fold increase in the total number of myelinated fibers with a decrease in average fiber size.

2. A 2- to 3-fold increase in nodes per unit length for larger diameter fibers and an overall 2.36-fold increase in nodes per unit weight of lumbosacral ventral root.

3. A 3.5-fold increase in ${ }^{3} \mathrm{H}-\mathrm{STX}$ binding per unit weight of aggregate ventral root.

4. A 6.2-fold increase in nodes per anterior horn cell which results from neuronal dropout and axonal branching of surviving neurons.

5. An increase in the number of binding sites per node in regenerated peripheral nerve from $1.26 \times 10^{6}$ to $1.95 \times 10^{6}$ (not statistically significant).

The implications of such channel reorganization include an increased metabolic load, both on the synthetic capacity of the neuron and on the oxidative metabolism of the fiber.

\section{References}

Allt, G. (1969) Repair of segmental demyelination in peripheral nerves: An electron microscope study. Brain 92: 639-646.

Allt, G. (1976) Pathology of the peripheral nerve. In The Peripheral Nerve, D. Landon, ed., pp. 666-739, Chapman and Hall, London.

Armstrong, C. (1981) Sodium channels and gating currents. Physiol. Rev. 61: 644-683.

Bergman, R. A., and A. K. Afifi (1974) In Atlas of Microscopic Anatomy, p. 134, Saunders, Philadelphia.

Berthold, C. H. (1968) Ultrastructure of the node-paranode region of mature feline ventral lumbar spinal root fibers. Acta Soc. Med. Upsaliensis $73:$ 37-70.

Berthold, C. H. (1978) Morphology of normal peripheral nerve. In Physiology and Pathobiology of Axons. S. G. Waxman, ed., pp. 3-63, Raven, New York.

Bevington, P. R. (1969) Data Reduction and Error Analysis for the Physical Sciences, pp. 204-245, McGraw-Hill, New York.

Bostock, H., and T. A. Sears (1976) Continuous conduction in demyelinated mammalian nerve fibers. Nature 263: 786-787.

Bray, G. M., M. Rasminsky, and A. J. Aguayo (1981) Interactions between axons and sheath cells. Annu. Rev. Neurosci. 4: 127-162.

Catterall, W. A. (1980) Neurotoxins that act on voltage-sensitive sodium channels in excitable membranes. Annu. Rev. Pharmacol. Toxicol. 20: 15-43.

Chiu, S. Y. (1980) Asymmetry currents in the mammalian myelinated nerve. J. Physiol. (Lond.) 309: 499-519.

Chiu, S. Y., and J. M. Ritchie (1982) Evidence for potassium channels in the internode of frog myelinated fibers. J. Physiol. (Lond.) 322: 485-501.

Chiu, S. Y., J. M. Ritchie, R. B. Rogart, and D. Stagg (1979) A quantitative description of membrane currents in rabbit myelinated nerve versus frog. J. Physiol. (Lond.) 292: 149-166.

Coggeshall, R. E., J. D. Coulter, and L. D. Willis (1974) Unmyelinated axons in the ventral roots of the cat lumbosacral enlargement. J. Comp. Neurol. 153: 39-58.

Colquhoun, D., R. Henderson, and J. M. Ritchie (1972) The binding of labelled tetrodotoxin to non-myelinated nerve fibers. J. Physiol. (Lond.) 277: 95-126.

Conti, F., L. J. DeFelice, and E. Wanke (1975) Potassium and sodium ion current noise in the membrane of the squid giant axon. J. Physiol. (Lond.) 248: 45-82.

Conti, F., B. Hille, B. Neumcke, W. Noner, and R. Stampfli (1976) Conductance of the sodium channel in myelinated nerve fibers with modified sodium innactivation. J. Physiol. (Iond.) 262: 729-742.

Cowan, W. M., and D. F. Wann (1973) A computer system for the measurement of cell and nuclear sizes. J. Microsc. 99: 331-340.

Culp, W. J., and D. T. McKenzie (1981) Detergent extraction of a presumptive gating component from the voltage-dependent sodium 
channel. Proc. Natl. Acad. Sci. USA 78: 7171-7175.

Feasby, T. E., A. H. Pullen, and T. A. Sears (1981) A quantitative ultrastructural study of dorsal root regeneration. J. Neurol. Sci. 49: 363-386.

Foster, R. E., C. C. Whalen, and S. G. Waxman (1980) Reorganization of the axon membrane in demyelinated peripheral nerve fibers: Morphological evidence. Science 210: 661-663.

Fried, K., C. Hildebrand, and G. Erdelyi (1982) Myelin sheath thickness and internodal length of nerve fiber in the developing feline inferior alveolar nerve. J. Neurol. Sci. 54: 47-57.

Gamble, H. J. (1976) Spinal and cranial nerve roots. In The Peripheral Nerve, D. Landon, ed., pp. 330-354, Chapman and Hall, London.

Ghatak, N. R., A. Hirano, H. Lijtmaer, and H. M. Zimmerman (1974) Asyptomatic demyelinated plaque. Arch. Neruol. 30: 484-486.

Gledhill, R. F., B. Harrison, and W. I. McDonald (1973) Pattern of remyelination in central nervous system. Nature 244: 443-444.

Griffin, J., D. L. Price, D. B. Drachman, and J.Morris (1981) Incorporation of axonally transported glycoproteins into axolemma during nerve regeneration. J. Cell Biol. 88: 205-214.

Guth, L. (1956) Regeneration in the mammalian peripheral nervous system. Physiol. Rev. 36: 441-471.

Herndon, R. M., D. L. Price, and L. P. Weiner (1977) Regeneration of oligodendroglia during recovery from demyelinating disease. Science 195: 693-694.

Hiscoe, W. B. (1947) The distribution of nodes and incisures in normal and regenerated nerve fibers. Anat. Rec. 99: 447-475.

Hursh, J. B. (1939) Conduction velocity and diameter of nerve fibers. Am. J. Physiol. 127: 131-139.

Husley, A. F., and R. Stampfli (1949) Evidence for saltatory conduction in peripheral myelinated nerve fibers. J. Physiol. (Lond.) 108: 315-339.

Keynes, R. D., F. Bezenilla, E. Rojas, and R. E. Taylor (1975) The rate of action of TTX on sodium conductance in squid giant axon. Phil. Trans. R. Soc. London [Biol.] 270: 365-375.

LaFontaine, S., M. Rasminsky, T. Saida, and A. Sumner (1982) Conduction block in rat myelinated fibers following acute exposure to antigalactocerebroside serum. J. Physiol. (Lond.) 323: 287-306.

Lazdunski, M., M. Balerna, J. Barhanin, R. Chicheportiche, et al. (1980) Molecular aspects of the structure and mechanism of voltage-dependent sodium channel. Ann. NY Acad. Sci. 358: 169-182.

Levinson, S. R. (1975) The purity of tritiated tetrodotoxin as determined by bioassay. Phil. Trans. R. Soc. [Biol.] 270: 337-348.

McDonald, W. I. (1963) The effects of experimental demyelination on conduction in peripheral nerve. Brain 86: 481-524.

McDonald, W. I. (1974a) Pathophysiology in multiple sclerosis. Brain 97: $179-196$.

McDonald, W. I. (1974b) Remyelination in relation to clinical lesions of the central nervous system. Br. Med. Bull. 30: 186-189.

McDonald, W. I., and T. A. Sears (1970) The effects of experimental demyelination on conduction in the central nervous system. Brain 93: 583-598.

Miller, J., S. Levinson, W. Agnew, and M. Ellisman (1982) Purification, composition and visualization of a tetrodotoxin-binding glycoprotein. Biophys. J. 37: 385a.

Morgan-Hughes, J. A. (1968) Experimental diphtheritic neuropathy: A pathological and electrophysiological study. J. Neruol. Sci. 7: 157175.

Namerow, N. S., and L. R. Thompson (1969) Plaques, symptoms and the remitting course of multiple sclerosis. Neurology 19: 765-774.

Nettler, J., and W. Wasserman (1974) Applied Linear Statistical Models: Regression, Analysis of Variance and Experimental Designs, pp. 7792, R. D. Irwin, Homewood, IL.

Neumche, B., and R. Stampfli (1982) Conductance and number of $\mathrm{Na}$ channels in rat myelinated nerve fibers. Physiol. Soc. Proc. 69 p.

Nonner, W., E. Rojas, and R. Stampfli (1975) Displacement currents in the node of Ranvier - voltage and time dependence. Pfluegers Arch. 354: $1-18$.

Oaklander, A. L., R. S. Pellegrino, and J. M. Ritchie (1984) STX binding to central and peripheral ncrvous tissue of myelin deficiency mutant rat. Brain Res. 307: 393-397.

Parhad, I. M., J. W. Griffin, D. L. Price, J. F. Koves, and D. O. Kuethe (1982) Fucosyl glycoprotein distribution in the demyelinated peripheral nerve. Soc. Neurosci. Abstr. 12.11

Prineas, J. W., and F. Connell (1979) Remyelination in multiple sclerosis. Ann. Neurol. 5: 22-31.
Rasminsky, M. (1980) Ephaptic transmission between single nerve tibers in the spinal nerve roots of dystrophic mice. J. Physiol. (Lond.) 305: 151-169.

Rasminsky, M., and R. E. Kearney (1976) Continuous conduction in large diameter bare axons in spinal roots of dystrophic mice. Neurology 26: 367 .

Rasminsky, M., and T. A. Sears (1972) Internodal conduction in undissected demyelinated nerve fibers. J. Physiol. (Lond.) 227: $323-$ 350.

Reinhard, J., and H. S. Jennings (1961) Anatomy of the cat. Holt, Reinhart, Winston, New York.

Ritchie, J. M. (1978) The sodium channel as a drug receptor. In Cell Mermbrane Receptors for Drugs and Hormones, R. W. Straub and L. Bolis, eds., pp. 227-242, Raven, New York.

Ritchie, J. M. (1979) Sodium channels in muscle and nerve. In Current Topics in Nerve and Muscle Research, A. Aguayo and G. Karpati, eds., pp. 210-219, Excerpta Medica, Amsterdam.

Ritchie, J. M., and R. B. Rogart (1977a) Density of sodium channels in mammalian myelinated nerve fibers and nature of the axonal membrane under the myelin sheath. Proc. Natl. Acad. Sci. USA 74: 211 215 .

Ritchie, J. M., and R. B. Rogart (1977b) Physiological basis of conduction in myelinated nerve fibers. In Myelin, P. Morrel, ed., pp. 117-158, Plenum, New York.

Ritchie, J. M., and R. B. Rogart (1977c) Pathophysiology of conduction in demyelinated nerve fibers. In Myelin, P. Morrel, ed., pp. 353 382, Plenum, New York.

Ritchie, J. M., and H. P. Rang (1983) Extra neuronal STX binding sites in rabbit myelinated nerve. Proc. Natl. Acad. Sci. USA 80: 2803$280 \%$

Ritchie, J. M., R. B. Rogart, and E. R. Strichartz (1976) A new method for labelling saxitoxin and its binding to non-myelinated fibers of the rabbit vagus, lobsterwalking leg and garfish olfactory nerves. J. Physiol. (Lond.) 261: 477-494.

Ritchie, J. M., H. P. Rang, and R. Pellegrino (1981) Sodium and potassium channels in demyelinated and remyelinated mammalian nerve. Nature 294: 257-259.

Rojas, E., and R. D. Keynes (1975) On the relation between displace ment currents and activation of sodium conductance in squid giant axon. Phil. Trans. R. Soc. London [Biol.] 270: 459-482.

Romanes, G. J. (1951) Motor cell columns of lumbosacral spinal cord of cat. J. Comp. Neurol. 94: 313-363.

Saida, K., A. J. Sumner, T. Saida, M. J. Brown, and D. H. Silberberg (1980) Antiserum-mediated demyelination: Relationship between remyelination and functional recovery. Ann. Neurol. 8: 12-24.

Sanders, F. K., and D. Whitteridge (1946) Conduction velocity and myelin thickness in regenerating nerve fibers. J. Physiol. (Lond.) 105 . 152-174.

Schnepp, P., and G. Schnepp (1971) Faseranalytische Untersuchungen an peripheren Nerven bei Tieren verschiedenes Grosse. Z. Zellforsch. 119: 99-114.

Shawe, G. D. (1955) On the number of branches formed by regenerating nerve fibers. Br. J. Surg. 42: 474-488.

Shrager, P., S. Y. Chiu, and J. M. Ritchie (1985) Voltage-dependent sodium and potassium channels in mammalian cultured Schwann cells. Proc. Natl. Acad. Sci. USA 82: 948-952.

Sigworth, F. J. (1980) The variance of sodium current fluctuations at the node of Ranvier frog node. J. Physiol. (Lond.) 307: 97-129.

Sjöstrand, J., Carlsson, C. A., and C. A. Thulin (1969) Regeneration of ventral roots. Acta Anat. 74: 532-546.

Smith, K. J., and S. M. Hall (1980) Nerve conduction during peripheral demyelination and remyelination. J. Neurol. Sci. 48: 201-219.

Smith, K. J., H. Bostock, and S. M. Hall (1982) Saltatory conduction precedes myelination in axons demyelinated with lysophosphatidyl choline. J. Neurol. Sci. 54: 13-31.

Strichartz, G. R., Rogart, R. B., and J. M. Ritchie (1979) Binding of radioactively labelled saxitoxin to squid giant axon. J. Memb. Biol. 48: 357-364.

Sunderland, S., and J. D. Lavarack (1953) The branching of nerve fibers. Acta Anat. 17: 46-59.

Thulin, C. A., and C. A. Carlsson (1969) Regeneration of transected ventral roots submitted to nanomolecular filter tubulation. $J$. Neurol. Sci. 8: 485-505.

Villegas, J., C. Sevcik, F. Barnola, and R. Villegas (1976) Grayanotoxin, veratrine and tetrodotoxin sensitive sodium pathways in the 
Schwann cell membrane of squid nerve fibers. J. Gen. Physiol. 67: 369-380.

Vizoso, A. D., and J. Z. Young (1948) Internode length and fiber diameter in developing and regenerating nerves. J. Anat. 82:110131.

Waxman, S. G. (1978) Prerequisites for conduction in demyelinated fibers. Neurology 28: 27-33.

Waxman, S. G., and M. H. Brill (1978) Conduction through demyelinated plaques in multiple sclerosis: Computer simulations of facilitation by short internodes. J. Neurol. Neurosurg. Psychiatr. 41:408417.

Waxman, S. G., and J. M. Ritchie (1981) Demyelinating disease: Basic and clinical electrophysiology. In Advances in Neurolngy, Raven, New York.

Willis, W. D., and R. E. Coggeshall (1978) Sensory Mechanisms of the Spinal Cord, Plenum, New York.

Wisniewski, A. M., D. Oppenheimer, and W. I. McDonald (1976) Relation between myelination and function in MS and EAE. Am. J. Neuropathol. 35: 327 (abstr.).

Yates, A. J., J.-P. Bouchard, and J. R. Wherrett (1976) Relation of axon membrane to myelin membrane in sciatic nerve during development: Comparison of morphological and chemical parameters. Brain Res. 104: 264-271. 